\title{
DINAMIKA RUANG WISATA RELIGI MAKAM SUNAN GIRI DI KABUPATEN GRESIK
}

\author{
Budi Santosa, Antariksa, Lisa Dwi Wulandari \\ Program Magister Arsitektur Lingkungan Binaan \\ Fakultas Teknik Universitas Brawijaya Malang \\ budisantosa777@gmail.com
}

\begin{abstract}
Space is the product of an activity, which involves economic and technical activities owned by a group of people, so it has political and strategic nature. The relationship between space and activity is very close, where the space has a concept of a container and content. This study concerns the dynamics of space in Sunan Giri Tomb formed because of the conflict and activities in the tomb tourist site. The visitors's space dimension of Sunan Giri Tomb can not be physically limited as each visitor has his own movement space and purpose of his activities. The aim of this study is to analyze the dynamics of space for visitor's activity in the tomb. The method used is descriptive qualitative, deciphering the visitor's behavior as the research object. The finding shows that space once had a specific function, but because of the activity and condition adjustment at one time, then the dynamics in space happen. The dynamics contain changes in the function and meaning or the space character which is associated with the context of time and influenced by human activities.
\end{abstract}

Ruang adalah produk aktivitas, yang melibatkan aktivitas ekonomi dan teknik yang dimiliki sekelompok masyarakat, sehingga sifatnya politis dan strategis. Hubungan aktivitas dan ruang sangat erat, dimana konsep ruang sebagai wadah (of space) dan pengisinya (in space). Penelitian ini mengenai dinamika ruang pada Makam Sunan Giri yang terbentuk karena konflik dan aktivitas di wisata religi Makam Sunan Giri. Dimensi ruang peziarah Makam Sunan Giri tidak bisa dibatasi secara fisik karena masing-masing memiliki ruang gerak 
dan maksud atas aktivitasnya. Tujuan dari penelitian ini yaitu menganalisis dinamika ruang terhadap aktivitas peziarah Makam Sunan Giri. Metode penelitian menggunakan deskriptif kualitatif, dengan menjelaskan perilaku para peziarah sebagai objek penelitian. Hasil penelitian menemukan bahwa ruang pada awalnya memiliki fungsi tertentu, namun karena adanya aktivitas dan penyesuaian kondisi pada satu waktu terjadilah dinamika pemanfaatan ruang. Dinamika tersebut meliputi perubahan fungsi dan makna atau karakter ruang yang terkait dengan konteks waktu dan dipengaruhi aktivitas manusia.

Keywords: dynamics, space and activities

\section{Pendahuluan}

Sejarah Islam di Indonesia sangatlah kompleks, mencerminkan keanekaragaman dan kesempurnaan tersebut ke dalam kultur. Sebelum agama Islam menyebar di Indonesia, mayoritas penduduk Indonesia beragama Hindu dan Budha. Banyak bukti-bukti tentang arsitektur bernuansa Budha dan patung-patung Budha yang menyebar di Indonesia. Namun ketika ada pelopor-pelopor dan penyebar Islam di Jawa, masyarakat telah beralih agama ke Islam. Banyak faktor yang mempengaruhi penyebaran dan perubahan agama mereka. Seketika itulah agama Islam menyebar di pulau Jawa. Peloporpelopor itu disebut dengan walisongo, mereka menyebar ke beberapa kota untuk mendirikan sebuah pondok pesantren dan mengajarkan agama Islam di Jawa.

Seiring dengan berjalannya waktu, para wali songo meninggal dunia, peningggalan-peninggalan mereka dijaga dan dilindungi oleh sahabat dan keturunan wali songo tersebut. Arsitektur Islam seperti masjid, halaman, perkampungan, dan lain sebagainya juga dilindungi dan dilestarikan oleh sahabat dan keturunan para wali tersebut, termasuk makam-makam sahabat wali, makam-makam keturunan/keluarga wali maupun para wali songo itu sendiri.

Masyarakat Indonesia yang beragama Islam ini merasa bahwa mereka harus mendoakan dan ikut meramaikan dengan acara-acara Islami, yaitu dengan berkunjung di Makam para wali (sunan) tersebut. Karena banyaknya para pengunjung di Indonesia yang ingin mendoakan para wali tersebut, maka pemerintah juga ikut melestarikan dan menjaga makam tersebut.Kemudian pemerintah memutuskan untuk menjadikan makam para wali tersebut menjadi "Wisata Ziarah". 
Dengan diresmikannya makam para wali sebagai wisata ziarah, warga Indonesia semakin ramai berbondong-bondong untuk mendoakan. Bahkan ada wisata khusus yang diadakan hanya untuk mengunjungi makam para wali. Para pengunjung berdatangan dari dalam kota, luar kota, maupun luar pulau. Untuk menanggapi hal tersebut, warga sekitar memanfaatkanya dengan berdagang berbagai produk, seperti baju, makanan, suvenir dan banyak lagi barang dagangan untuk meramaikan fasilitas tersebut.

Sunan Giri adalah salah satu Wali Allah di antara para Walisongo, beliau adalah pejuang dari penyebar agama Islam di Pulau Jawa. Sunan Giri merupakan ulama yang terkenal dan negarawan yang cukup berperan di awal Kerajaan Islam Demak, juga masih keturunan ke 23 (dua puluh tiga) dari junjungan Nabi Besar Muhammad SAW,yang merupakan salah satu Wali Songo yang berada di Kota Gresik. Dengan nama kecil Raden Paku atau Joko Samudro yang lahir pada Tahun 1422 M. Masa pemerintahan Sunan Giri di Kerajaan Giri Kedaton dengan Gelar Prabu Satmoto yaitu pada masa 1487 s/d 1506 M. Sunan Giri wafat pada tahun 1506 M.

Kondisi makam Sunan Giri secara sekilas masih mempunyai ciri khas dengan motif arkeologi peninggalan pada masa awal agama Islam, seperti gapura pintu masuk makam terbuat dari batu yang berbentuk sepasang kepala naga raja, bangunan beratap di atas makam sebagai pelindung makam (rumah kubur) terbuat dari kayu jati asli, dindingnya terdiri dari panel (disebut juga lumber sering) tumbuh-tumbuhan, sedangkan pintu cungkup terdapat ukliran bermotif Hindu yang dipadukan dengan motif islami yaitu tumbuhtumbuhan. Wisata ziarah makam Sunan Giri mempunyai potensi alam yang sangat menarik, serta kontur-kontur alam yang unik jika ditata lebih lanjut. Kondisi fisik wisata ziarah makam Sunan Giri terlihat berubah karakternya dan terjadi penurunan makna nilai-nilai dan konsepsi kawasan makam sebagai wujud pelestarian kearifan lokal dalam behavioral mapping.

Ruang adalah sistem lingkungan binaan terkecil yang sangat penting, terutama sebagian besar waktu manusia modern saat ini banyak dihabiskan di dalamnya. Dalam arsitektur lingkungan dan perilaku, ruang diartikan sebagai suatu petak yang dibatasi oleh dinding dan atap baik dari unsur yang permanen maupun tidak permanen. Dalam kaitannya dengan manusia, hal yang penting dari pengaruh ruang terhadap perilaku manusia adalah fungsi atau pemakaian ruang tersebut. Dimensi ruang pengguna makam Sunan Giri tidak bisa dibatasi secara fisik karena masing-masing pengguna memiliki cacthment area, yaitu batas non fisik dari teritori ruang gerak pengguna, yang didasarkan pada 
batas pandangan, batas rasa, batas oleh panca indera, imajinasi dan keinginan masing-masing pengguna atas tujuan mereka melakukan aktivitas.

Penelitian tentang dinamika ruang yang terbentuk karena untuk adanya aktivitas pengguna wisata ziarah makam Sunan Giri diperlukan untuk pengembangan wisata ziarah makam Sunan Giri. Dengan harapan kedepannya dapat mewadahi kebutuhan aktivitas masyarakat sebagai ruang terbuka publik dengan tanpa meninggalkan nilai-nilai dan konsepsi makam Sunan Giri sebagai wujud pelestarian kearifan lokal arsitektur Islam.

\section{Metode Penelitian}

Penelitian ini merupakan penelitian deskriptif kualitatif yang bertujuan untuk menggali dan mendeskripsikan dinamika ruang aktivitas penggunaan wisata ziarah makam Sunan Giri. Pendekatan deskriptif dilakukan untuk menggambarkan dan menginterpretasikan objek studi, yaitu untuk mengetahui dan mendalami aktivitas penggunaan makam Sunan Giri sebagai ruang aktivitas publik.

Metode penelitian menggunakan deskriptif kualitatif, dengan menganalisis perilaku para peziarah kawasan makam Sunan Giri, yang sangat berhubungan dengan lokalitas ruang dan aktivitas yang terdapat di kawasan makam Sunan Giri. Penelitian deskriptif kualitatif mampu menyajikan gambaran secara detail dari sebuah situasi dan atau setting, dari uraian tersebut maka secara diskriptif, penelitian ini dapat menggambarkan aktivitas peziarah di kawasan makam Sunan Giri (Neuman, 1997: 19).

Analisis perilaku para peziarah dilakukan dengan cara observing, documentation, dan depth interview. Secara sistematika adalah dengan memperhatikan para peziarah di kawasan makam Sunan Giri dalam memanfaatkan ruang ziarah, baik secara individual, kelompok besar ataupun kecil (Zeisel 1981: 111).

Populasi pada studi ini adalah yang menggunakan ruang ritual, sosial di makam Sunan Giri yang ditentukan dengan menggunakan teknik sampling, yaitu dari satu atau beberapa sampel tersebut semakin lama dapat menjadi lebih banyak, kemudian sampel dipilih kembali atas dasar fokus penelitian (Moleong, 2007: 224).

\section{Deskripsi Kawasan Penelitian}

Secara geografis, lokasi makam Sunan Giri berada di dusun Giri Gajah, Desa Giri Kecamatan Kebomas. Objek wisata religi makam Sunan Giri 
terletak sekitar $4 \mathrm{~km}$ dari pusat Kota Gresik. Wisata religi kompleks makam Sunan Giri berada di depan Jl. Sunan Prapen, Kebomas, Gresik, Jawa Timur. Lokasi Makam Sunan Giri dapat dijangkau dengan mudah oleh transportasi umum, dengan menggunakan kendaraan bermotor ditempuh dengan jarak $2 \mathrm{~km}$. menuju arah selatan dari Kota Gresik yang berada di puncak Bukit Giri. Komplek makam ini tepatnya berada di puncak Bukit Giri dan berada di tengah-tengah makam keluarga

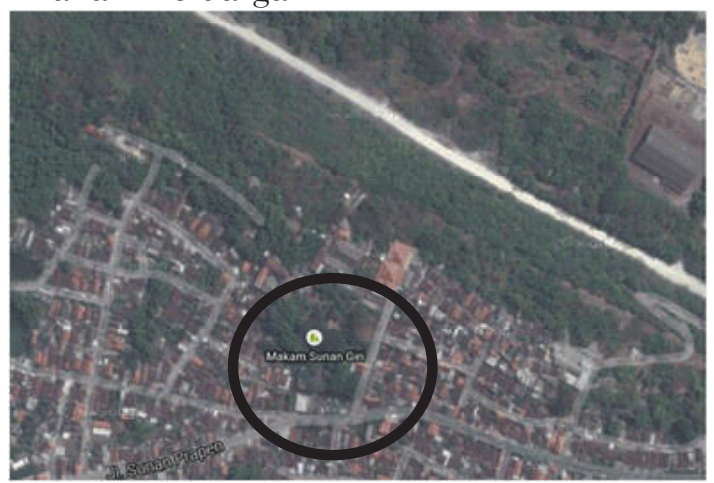

Gambar 1. Lokasi Makam Sunan Giri di Desa Giri, Kecamatan Kebomas, Kabupaten Gresik Sumber: maps.google.com
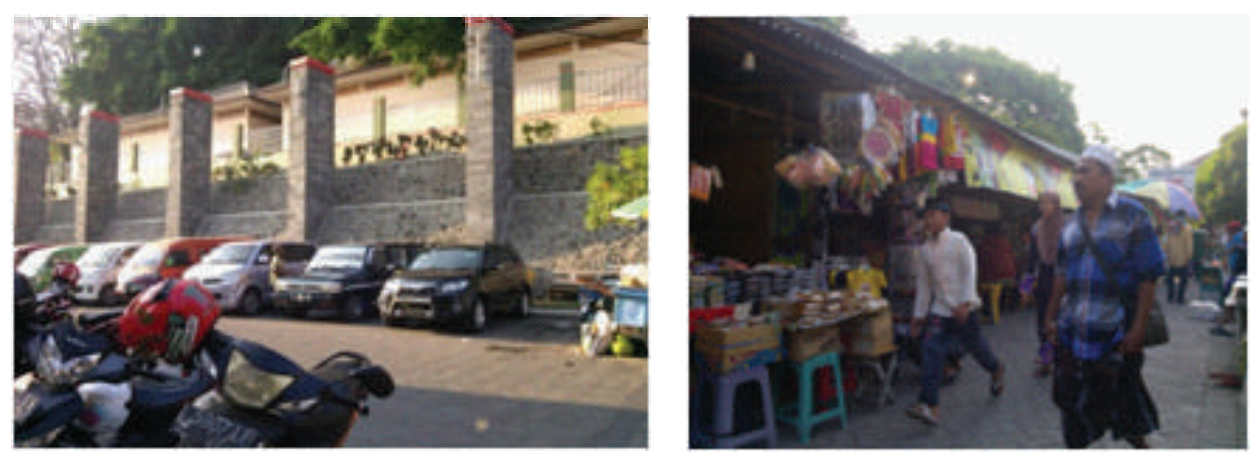

\section{Ruang di dalam Makam Sunan Giri}

Ruang di dalam area Makam Sunan Giri terdiri dari:

a. Parkir Mobil dan motor

Parkir mobil terletak di depan, dekat dengan pintu gerbang. Parkir mobil bersebelahan dengan parkir sepeda motor. Terdapat penjaga parkir yaitu 3-5 orang.

b. Toilet, tempat wudhu dan cuci kaki

Di dekat pintu gerbang juga terdapat toilet, tempat wudhu dan cuci kaki. 
Toilet di area makam Sunan Giri ada dua, yaitu di dekat pintu gerbang dan di dalam kompleks masjid. Pada umumnya, para peziarah lebih banyak menggunakan toilet di dekat pintu gerbang.

c. Stand PKL
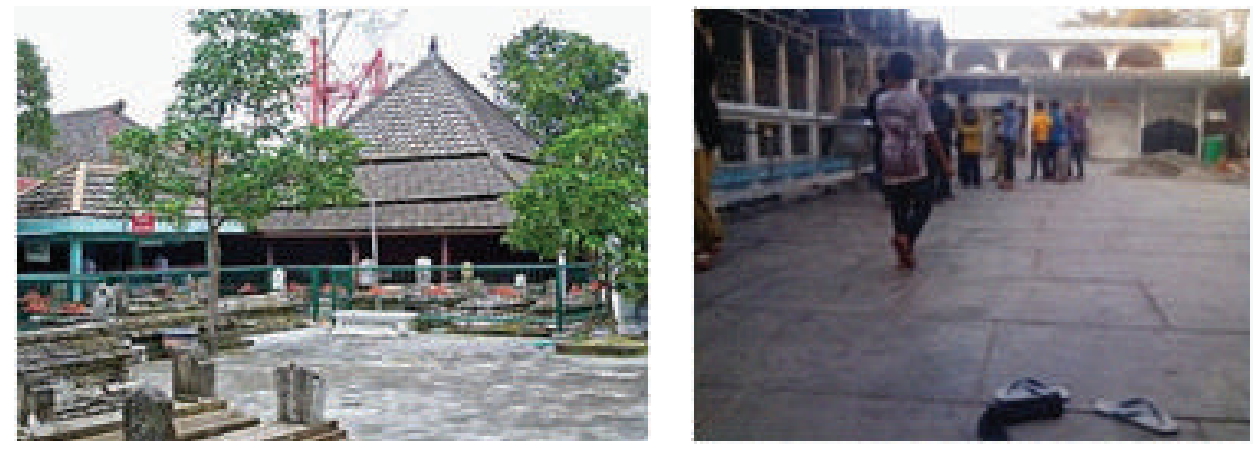

Pada makam Sunan Giri terdapat stand PKL yang lokasinya dekat dengan kompleks Makam. Pada tahun 2013, PKL banyak yang menempati kanan dan kiri tangga jalan. Untuk tahun 2014, sudah dilakukan penataan stand PKL. Stand PKL di Makam Sunan Giri berjualan beraneka jenis kebutuhan umat muslim.

Mulai dari pakaian muslim, perlengkapan salat, buku-buku Islam, kitab suci, kurma, alat-alat kesenian Islam dan makanan khas Kota Gresik seperti jenang ayas, pudak, nasi krawu serta minuman legen.

a. Jalur menuju Kompleks Makam

Selain makam utama Sunan Giri, pada komplek makam Sunan Giri juga terdapat beberapa makam lainnya yang berada di sisi kanan dan kiri jalan menuju situs utama. Peziarah hanya dapat melihat makam dari luar pagar. Pada jalur menuju Makam utama terdapat pengemis yang memintaminta.

b. Kantor Yayasan Makam Sunan Giri

Di sebelah timur makam Sunan Giri terdapat Kantor Yayasan Makam Sunan Giri yang bertugas sebagai pengelola kompleks Makam Sunan Giri. Ruang Kantor Yayasan Makam Sunan Giri ditempati oleh pengelola dan jarang peziarah menuju ruang tersebut.

c. Makam Utama Sunan Giri

Lokasi Makam utama Sunan Giri terletak di areal sebelah kiri masjid Giri Kedaton, dengan jumlah makam \pm 300 makam. Bentuknya terbuat dari batu hitam yang biasanya banyak digunakan untuk membuat candi atau 
arca di zaman kejayaan Hindu dan Budha.

Kondisi Makam Sunan Giri sendiri berada di dalam bangunan yang dihiasi banyak ornamen dengan motif sulur tanaman. Pintu masuk makam dibuat rendah sehingga pengunjung harus merunduk agar tidak terbentur. Hal ini disengaja sebagai penghormatan kepada Sunan Giri. Lokasi Makam Sunan Giri berada pada teras paling tinggi dan dikelilingi banyak makam lainnya.

d. Kompleks Masjid Jamik Sunan Giri

Luas lahan tanah Masjid Jamik Giri Kedaton adalah 3.000 m2 dengan luas bangunan $1.750 \mathrm{~m} 2$. Pada kompleks masjid terdapat ruang utama, mimbar, serambi, teras, tempat wudhu dan toilet.

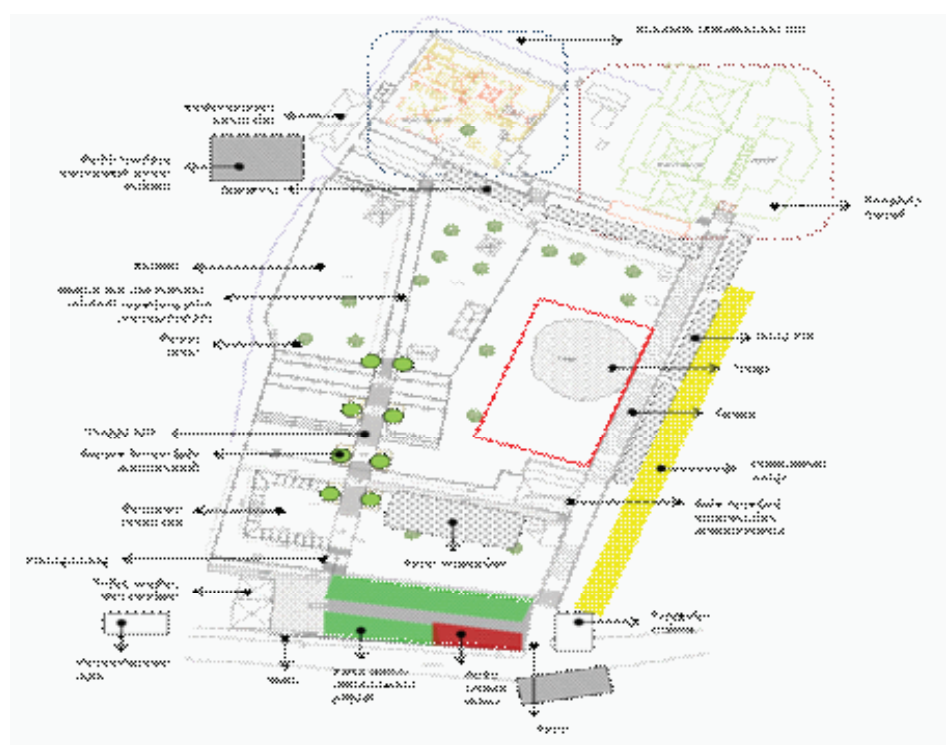

Gambar 2: Layout Makam Sunan Giri

\section{Jumlah dan waktu berziarah ke Makam Sunan Giri}

Jumlah peziarah di makam Sunan Giri pada Tahun 2013, yaitu sebesar 1.754.224 pengunjung, yang setiap bulannya rata-rata 146.185 pengunjung. Hasil rekapitulasi jumlah peziarah makam Sunan Giri, terbagi atas 4 (empat) kategori peziarah yaitu peziarah dari mancanegara, peziarah umum, peziarah pelajar dan peneliti/studi. Sejak periode tahun 2010 s/d tahun 2013 dapat dilihat nilai terbesar adalah peziarah umum, yaitu $98,20 \%$, peziarah dari mancanegara sebesar $0,02 \%$, peziarah pelajar $1,77 \%$ dan peziarah yang melakukan studi/ 
penelitian sebanyak 0,01\% (sumber: Yayasan Makam Sunan Giri).

Makam Sunan Giri dipadati pengunjung pada hari biasa dan juga pada hari Sabtu-Minggu. Selain hari itu, makam Sunan Giri dipadati peziarah pada malam selawe (malam ke-25 bulan Ramadhan) dan saat haul Sunan Giri (tiap Jumat terakhir bulan Robiul Awwal). Jumlah pengunjung hari biasa yaitu 50100 orang per hari. Jumlah pengunjung saat hari libur (Sabtu dan Minggu) yaitu 500-1000 orang per hari. Jumlah pengunjung saat malam selawe untuk pagi sampai sore harinya mencapai 500 hingga 1000 orang perhari, pada saat Malam Selawe naik hingga 2.500 pengunjung perhari untuk beri'tikaf. Jumlah pengunjung saat haul Sunan Giri yakni mencapai lebih dari 2000 orang.

\section{Identifikasi dan Analisis Pola Aktivitas di Dalam Ruang Makam Sunan Giri}

Pola aktivitas pengguna di makam Sunan Giri dipengaruhi oleh: a. Aksesibilitas

Aksesibilitas menjadi faktor penentu dalam ketergunaan ruang di makam Sunan Giri. Ruang-ruang dengan aksesibilitas tinggi juga memiliki intensitas penggunaan publik yang tinggi. Aksesibilitas tidak terbatas pada akses fisik kepada ruang yang dimaksud, akan tetapi termasuk akses visual, misalnya adalah ruang pejalan kaki, pendopo dan makam utama Sunan Giri. Pada kasus ini terjadi konflik dalam pemanfaatan ruang pejalan kaki menuju makam yaitu ruang pejalan kaki lebih didominasi oleh pengemis dan mengganggu kenyamanan peziarah yang menuju makam utama.

b. Pendukung Aktivitas

Pendukung aktivitas yang mendorong penggunaan ruang adalah ketersediaan PKL, ketersediaan parkir dan peneduhan. Pada kasus penelitian, terjadi perubahan pengaturan pendukung aktivitas pada beberapa tahun terakhir yaini pemindahan PKL dari PKL yang berada di gerbang masuk di alokasikan di satu tempat yaitu Pasar Wisata Giri dan stand PKL di dekat makam.

c. Event-event Temporer

Pada saat temporer, terjadi peningkatan penggunaan ruang di Makam Sunan Giri, yaitu pada hari Sabtu dan Minggu dan acara khusus (Haul Sunan Giri, Malam Selawe). Terjadi perubahan aktivitas yang tinggi pada acara tersebut. Kadangkala terjadi peluberan sampai ruangan tidak dapat menampung banyaknya peziarah. 
Pola aktivitas publik di Makam Sunan Giri adalah sebagai berikut:

Tabel 1. Pola Aktivitas Publik di dalam ruang Makam Sunan Giri

\begin{tabular}{|c|c|c|}
\hline Tipologi Ruang & \multicolumn{2}{|c|}{ Aktivitas Publik di Makam Sunan Giri } \\
\hline \multirow{4}{*}{$\begin{array}{l}\text { Tempat Parkir } \\
\text { Motor dan Mobil }\end{array}$} & Waktu penggunaan & Harian, acara agama \\
\hline & $\begin{array}{l}\text { Aktivitas yang } \\
\text { berlangsung }\end{array}$ & $\begin{array}{l}\text { Parkir kendaraan dan tempat } \\
\text { pemberhentian }\end{array}$ \\
\hline & Pengguna & $\begin{array}{l}\text { Peziarah, tukang parkir, tukang } \\
\text { ojek, tukang andong }\end{array}$ \\
\hline & Aspek kualitas ruang & $\begin{array}{l}\text { Akses terbuka, peneduhan } \\
\text { terbatas } \\
\text { Pada acara agama: Daya tampung } \\
\text { parkir tidak memadai }\end{array}$ \\
\hline \multirow[t]{4}{*}{ Gerbang Masuk } & Waktu penggunaan & Harian, acara agama \\
\hline & $\begin{array}{l}\text { Aktivitas yang } \\
\text { berlangsung }\end{array}$ & Lalu lintas pejalan kaki \\
\hline & Pengguna & $\begin{array}{l}\text { Peziarah, masyarakat sekitar, } \\
\text { pedagang, pengelola }\end{array}$ \\
\hline & Aspek kualitas ruang & $\begin{array}{l}\text { Akses terbuka, menggunakan } \\
\text { arsitektur tradisional Jawa }\end{array}$ \\
\hline \multirow{4}{*}{$\begin{array}{l}\text { Toilet dan } \\
\text { Tempat Wudhu }\end{array}$} & Waktu penggunaan & Harian, acara agama \\
\hline & $\begin{array}{l}\text { Aktivitas yang } \\
\text { berlangsung }\end{array}$ & $\begin{array}{l}\text { Mandi, wudhu, buang air kecil, } \\
\text { cuci muka }\end{array}$ \\
\hline & Pengguna & $\begin{array}{l}\text { Peziarah, masyarakat sekitar, } \\
\text { pedagang, pengelola }\end{array}$ \\
\hline & Aspek kualitas ruang & $\begin{array}{l}\text { Bersih, akses untuk umum, } \\
\text { strategis }\end{array}$ \\
\hline \multirow{4}{*}{$\begin{array}{l}\text { Jalan menuju } \\
\text { makam }\end{array}$} & Waktu penggunaan & Harian, acara agama \\
\hline & $\begin{array}{l}\text { Aktivitas yang } \\
\text { berlangsung }\end{array}$ & Lalu lintas pejalan kaki \\
\hline & Pengguna & $\begin{array}{l}\text { Peziarah, pengemis, masyarakat } \\
\text { sekitar, pedagang,pengelola }\end{array}$ \\
\hline & Aspek kualitas ruang & $\begin{array}{l}\text { Akses terbuka, banyak pohon } \\
\text { peneduh, perkerasan } \\
\text { Semakin banyak pengemis jika } \\
\text { Hari Sabtu-Minggu dan acara } \\
\text { agama }\end{array}$ \\
\hline
\end{tabular}




\begin{tabular}{|c|c|c|}
\hline \multirow[t]{4}{*}{ Pasar Wisata Giri } & Waktu penggunaan & Harian, acara agama \\
\hline & $\begin{array}{l}\text { Aktivitas yang } \\
\text { berlangsung }\end{array}$ & Belanja, berdagang \\
\hline & Pengguna & Peziarah, pedagang \\
\hline & Aspek kualitas ruang & $\begin{array}{l}\text { Akses terbuka, cukup teratur, } \\
\text { peneduh sebagian } \\
\text { Harian: cukup sepi } \\
\text { Hari Sabtu-Minggu: cukup ramai } \\
\text { Acara agama: sangat ramai }\end{array}$ \\
\hline \multirow{4}{*}{$\begin{array}{l}\text { Kantor Yayasan } \\
\text { Sunan Giri }\end{array}$} & Waktu penggunaan & Harian \\
\hline & $\begin{array}{l}\text { Aktivitas yang } \\
\text { berlangsung }\end{array}$ & Pengawasan dan pengelolaan \\
\hline & Pengguna & Pengelola \\
\hline & Aspek kualitas ruang & Akses terbatas \\
\hline \multirow[t]{4}{*}{ Pendopo } & Waktu penggunaan & Harian, acara agama \\
\hline & $\begin{array}{l}\text { Aktivitas yang } \\
\text { berlangsung }\end{array}$ & $\begin{array}{l}\text { Wudhu, berdoa, membaca al } \\
\text { Quran, shalawatan }\end{array}$ \\
\hline & Pengguna & Peziarah, penjaga makam \\
\hline & Aspek kualitas ruang & $\begin{array}{l}\text { Ruangan terbuka, akses terbatas } \\
\text { Hari Biasa: Mampu menampung } \\
\text { Peziarah } \\
\text { Hari Sabtu-Minggu, acara agama: } \\
\text { Belum sepenuhnya menampung } \\
\text { peziarah }\end{array}$ \\
\hline \multirow{4}{*}{$\begin{array}{l}\text { Makam Utama } \\
\text { Sunan Giri }\end{array}$} & Waktu penggunaan & Harian, acara agama \\
\hline & $\begin{array}{l}\text { Aktivitas yang } \\
\text { berlangsung }\end{array}$ & Berdoa \\
\hline & Pengguna & Peziarah \\
\hline & Aspek kualitas ruang & Akses terbatas \\
\hline
\end{tabular}




\begin{tabular}{|c|c|c|}
\hline \multirow{4}{*}{$\begin{array}{l}\text { Makam Sunan } \\
\text { Prapen }\end{array}$} & Waktu penggunaan & Harian, Acara Agama \\
\hline & $\begin{array}{l}\text { Aktivitas yang } \\
\text { berlangsung }\end{array}$ & Berdoa \\
\hline & Pengguna & Peziarah \\
\hline & Aspek kualitas ruang & Akses terbatas \\
\hline \multirow[t]{4}{*}{ Masjid } & Waktu penggunaan & Harian, Acara Agama \\
\hline & $\begin{array}{l}\text { Aktivitas yang } \\
\text { berlangsung }\end{array}$ & Sholat, Wudhu, Istirahat \\
\hline & Pengguna & $\begin{array}{l}\text { Peziarah, Masyarakat Sekitar, } \\
\text { Pengelola }\end{array}$ \\
\hline & Aspek kualitas ruang & Akses terbatas, ruangan terbuka \\
\hline \multirow[t]{4}{*}{ Stand PKL } & Waktu penggunaan & Harian, Acara Agama \\
\hline & $\begin{array}{l}\text { Aktivitas yang } \\
\text { berlangsung }\end{array}$ & Belanja,berdagang \\
\hline & Pengguna & Peziarah,pedagang \\
\hline & Aspek kualitas ruang & $\begin{array}{l}\text { Akses terbuka, cukup teratur, } \\
\text { peneduh sebagian } \\
\text { Hari biasa: cukup ramai } \\
\text { Hari Sabtu-Minggu, Acara } \\
\text { keagamaan: sangat ramai }\end{array}$ \\
\hline \multirow{4}{*}{$\begin{array}{l}\text { Stand PKL menuju } \\
\text { Pintu Keluar }\end{array}$} & Waktu penggunaan & Harian, Acara Agama \\
\hline & $\begin{array}{l}\text { Aktivitas yang } \\
\text { berlangsung }\end{array}$ & Belanja, berdagang \\
\hline & Pengguna & Peziarah, pedagang \\
\hline & Aspek kualitas ruang & $\begin{array}{l}\text { Akses terbuka, cukup teratur, } \\
\text { peneduh sebagian, ramai } \\
\text { Hari biasa: cukup ramai } \\
\text { Hari Sabtu-Minggu, Acara } \\
\text { keagamaan: sangat ramai dan } \\
\text { meluber di luar parkiran }\end{array}$ \\
\hline
\end{tabular}

Sumber: Dokumentasi Pribadi (2014) 


\section{Identifikasi dan Analisis Penggunaan Ruang di Makam Sunan Giri pada Saat Hari Libur (Sabtu dan Minggu)}

Pada hari libur (Sabtu dan Minggu), makam Sunan Giri dipadati peziarah mulai dari pagi hari sampai dengan sore hari. Pada hari Sabtu dan Minggu, pada malam hari peziarah sudah banyak yang pulang dan tidak menginap. Aktivitas tinggi terjadi pada parkiran mobil dan motor, dikarenakan untuk hari libur mayoritas peziarah menggunakan mobil dan motor. Aktivitas tinggi lainnya adalah pada ruang pendopo, makam utama serta masjid.

Tabel 2. Penggunaan Ruang pada Makam Sunan Giri saat hari libur (Sabtu dan Minggu)

\begin{tabular}{|l|l|l|l|}
\hline Ruang & Kegiatan & Hari biasa & $\begin{array}{l}\text { Aktivitas pada hari } \\
\text { libur }\end{array}$ \\
\hline Parkir & $\begin{array}{l}\text { Parkir } \\
\text { kendaraan dan } \\
\text { pemberhentian } \\
\text { kendaraan }\end{array}$ & $\begin{array}{l}\text { Tidak dipenuhi } \\
\text { oleh kendaraan }\end{array}$ & $\begin{array}{l}\text { Parkiran motor dan } \\
\text { mobil dipadati oleh } \\
\text { peziarah }\end{array}$ \\
\hline $\begin{array}{l}\text { Jalur menuju } \\
\text { Makam }\end{array}$ & $\begin{array}{l}\text { Lalu Lintas } \\
\text { pejalan kaki, } \\
\text { ruang publik }\end{array}$ & $\begin{array}{l}\text { Pada hari biasa } \\
\text { juga terdapat } \\
\text { pengemis, } \\
\text { namun hanya } \\
\text { beberapa }\end{array}$ & $\begin{array}{l}\text { Terdapat banyak } \\
\text { pengemis dan penjual } \\
\text { makanan di sepanjang } \\
\text { jalur menuju makam } \\
\text { utama }\end{array}$ \\
\hline $\begin{array}{l}\text { Pendopo } \\
\text { dan Makam } \\
\begin{array}{l}\text { Utama } \\
\text { Sunan Giri }\end{array}\end{array}$ & $\begin{array}{l}\text { Wudhu, berdoa, } \\
\text { membaca } \\
\text { al Quran, } \\
\text { shalawatan }\end{array}$ & $\begin{array}{l}\text { Pada hari } \\
\text { biasa, jumlah } \\
\text { pengunjung } \\
\text { antara 50-an } \\
\text { orang per hari }\end{array}$ & $\begin{array}{l}\text { Jumlah peziarah 500- } \\
\text { 1000 orang per hari. } \\
\text { Di dalam pendopo dan } \\
\text { makam penuh sesak dan } \\
\text { harus antri untuk ke } \\
\text { makam utama }\end{array}$ \\
\hline
\end{tabular}




\begin{tabular}{|c|l|l|l|}
\hline Ruang & Kegiatan & Hari biasa & $\begin{array}{l}\text { Aktivitas pada hari } \\
\text { libur }\end{array}$ \\
\hline Stand PKL & $\begin{array}{l}\text { Berjualan dan } \\
\text { membeli }\end{array}$ & $\begin{array}{l}\text { Pada hari biasa, } \\
\text { stand PKL sepi } \\
\text { hanya terdapat } \\
\text { beberapa } \\
\text { peziarah yang } \\
\text { membeli }\end{array}$ & $\begin{array}{l}\text { Pada Sabtu dan Minggu, } \\
\text { aktivitas peziarah di } \\
\text { stand PKL cukup ramai. } \\
\text { Beberapa peziarah } \\
\text { membeli oleh-oleh. }\end{array}$ \\
\hline Masjid & $\begin{array}{l}\text { Sholat, wudhu, } \\
\text { istirahat }\end{array}$ & $\begin{array}{l}\text { Pada hari biasa, } \\
\text { hanya digunakan } \\
\text { untuk sholat }\end{array}$ & $\begin{array}{l}\text { Pada hari libur Sabtu } \\
\text { dan Minggu, selain } \\
\text { digunakan untuk sholat } \\
\text { juga digunakan peziarah } \\
\text { untuk istirahat }\end{array}$ \\
\hline
\end{tabular}

Sumber: Dokumentasi Pribadi (2014)

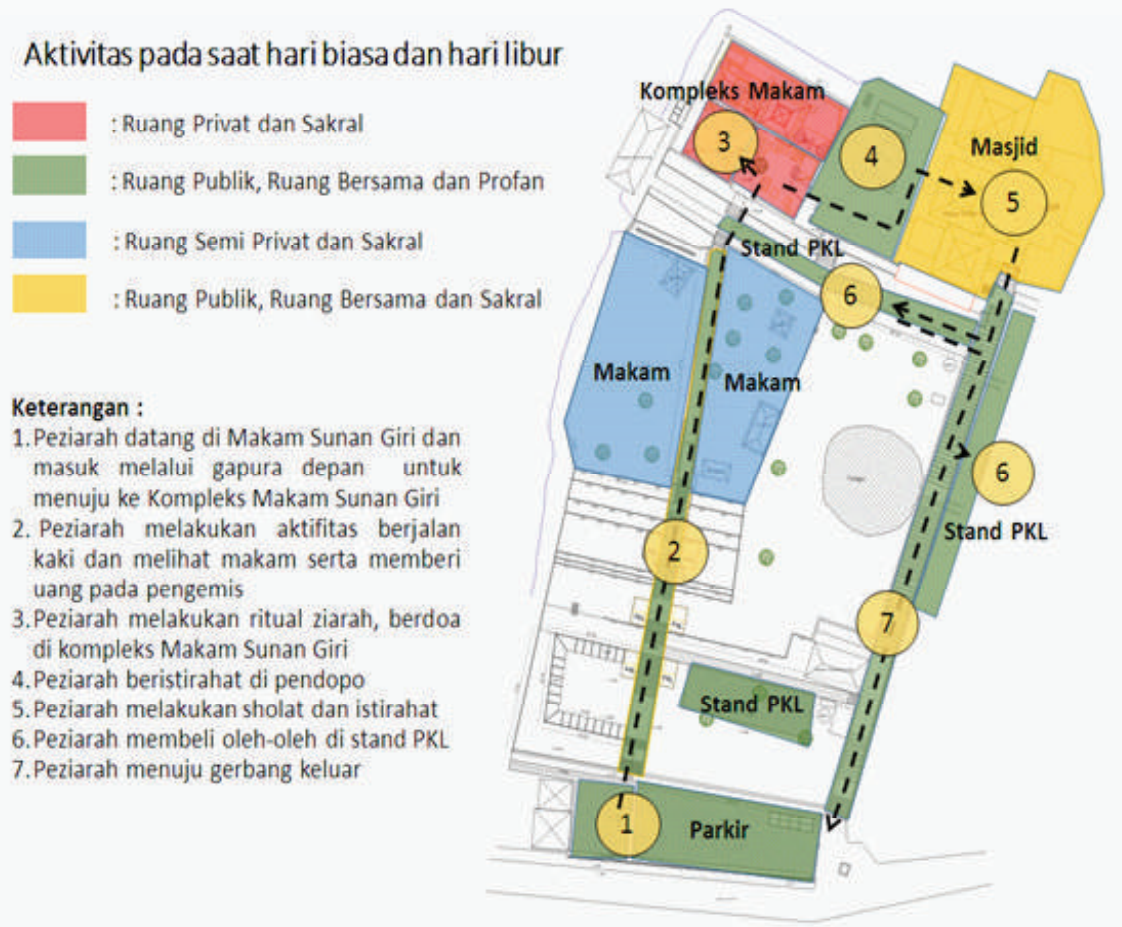

Gambar 3.Penggunaan Ruang saat Hari Biasa dan Hari Libur 


\section{Identifikasi dan Analisis Penggunaan Ruang Pada Saat Acara Malam Selawe}

Pada saat acara keagamaan (malam selawe), makam Sunan Giri dipadati peziarah mulai dari pagi hari sampai dengan esok harinya. Para peziarah kebayakan menginap.Tujuan utama malam 25 Ramadhan di Sunan Giri ini, selain untuk berziarah ke makam Sunan Giri juga melakukan i’tikaf di Masjid Jami' Sunan Giri.

Tabel 3. Penggunaan Ruang pada Makam Sunan Giri saat Malam Selawe

\begin{tabular}{|c|c|c|c|}
\hline Ruang & Kegiatan & Hari Biasa & Aktivitas saat Malam Selawe \\
\hline Parkir & $\begin{array}{l}\text { Parkir } \\
\text { kendaraan dan } \\
\text { pemberhentian } \\
\text { kendaraan }\end{array}$ & $\begin{array}{l}\text { Tidak dipenuhi } \\
\text { oleh kendaraan }\end{array}$ & $\begin{array}{l}\text { Parkir kendaraan dipenuhi } \\
\text { oleh peziarah yang datang } \\
\text { hingga ribuan orang. } \\
\text { Pada saat Malam Selawe, } \\
\text { masyarakat sekitar juga } \\
\text { menyediakan parkir } \\
\text { swadaya untuk menampung } \\
\text { para peziarah }\end{array}$ \\
\hline $\begin{array}{l}\text { Jalur } \\
\text { menuju } \\
\text { Makam }\end{array}$ & $\begin{array}{l}\text { Lalu Lintas } \\
\text { pejalan kaki, } \\
\text { ruang publik }\end{array}$ & $\begin{array}{l}\text { Pada hari biasa } \\
\text { juga terdapat } \\
\text { pengemis, } \\
\text { namun hanya } \\
\text { beberapa }\end{array}$ & $\begin{array}{l}\text { Pada saat Malam Selawe, } \\
\text { pengemis tidak hanya } \\
\text { di jalan menuju makam } \\
\text { utama. Namun juga pada } \\
\text { pintu masuk dan pintu } \\
\text { keluar. Bahkan terdapat } \\
\text { pengemis yang datang ke } \\
\text { masjid untuk meminta- } \\
\text { minta. }\end{array}$ \\
\hline $\begin{array}{l}\text { Pendopo } \\
\text { dan } \\
\text { Makam } \\
\text { Utama } \\
\text { Sunan } \\
\text { Giri }\end{array}$ & $\begin{array}{l}\text { Wudhu, berdoa, } \\
\text { membaca } \\
\text { al Quran, } \\
\text { shalawatan }\end{array}$ & $\begin{array}{l}\text { Pada hari } \\
\text { biasa, jumlah } \\
\text { pengunjung } \\
\text { antara 50-an } \\
\text { orang per hari }\end{array}$ & $\begin{array}{l}\text { Pada saat Malam Selawe, } \\
\text { pendopo dan makam } \\
\text { utama dipenuhi oleh para } \\
\text { peziarah dan masyarakat } \\
\text { sekitar yang berdoa di } \\
\text { Malam Selawe. } \\
\text { Bahkan ada yang berada di } \\
\text { Masjid untuk mengantri } \\
\text { dan berada di luar } \\
\text { pendopo. }\end{array}$ \\
\hline
\end{tabular}




\begin{tabular}{|l|l|l|l|}
\hline Ruang & Kegiatan & Hari Biasa & Aktivitas saat Malam Selawe \\
\hline $\begin{array}{l}\text { Stand } \\
\text { PKL }\end{array}$ & $\begin{array}{l}\text { Berjualan dan } \\
\text { membeli }\end{array}$ & $\begin{array}{l}\text { Pada hari biasa, } \\
\text { stand PKL sepi } \\
\text { hanya terdapat } \\
\text { beberapa } \\
\text { peziarah yang } \\
\text { membeli }\end{array}$ & $\begin{array}{l}\text { Pada saat Malam Selawe, } \\
\text { stand dipenuhi oleh } \\
\text { penjual dan peziarah. } \\
\text { Para PKL tidak hanya } \\
\text { terdapat pada tempat yang } \\
\text { disedakan namun di depan } \\
\text { parkiran, di depan pintu } \\
\text { masuk dan di jalanan } \\
\text { menuju makam Sunan } \\
\text { Giri. }\end{array}$ \\
\hline Masjid & $\begin{array}{l}\text { Sholat, wudhu, } \\
\text { istirahat }\end{array}$ & $\begin{array}{l}\text { Pada hari biasa, } \\
\text { hanya digunakan } \\
\text { untuk sholat }\end{array}$ & $\begin{array}{l}\text { Pada saat Malam Selawe, } \\
\text { masjid digunakan sebagai } \\
\text { tempat i'tikaf. }\end{array}$ \\
\hline
\end{tabular}

Sumber: Dokumentasi Pribadi (2014)

\section{Aktivitas pada saat Malam Selawe}

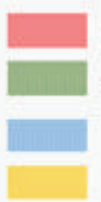

; Ruang Privat dan Sakral

: Ruang Publik, Ruang Bersama dan Profan

:Ruang Semi Privat dan Sakral

: Ruang Publik, Ruang Bersama dan Sakral

\section{Keterangan :}

1.Peziarah datang di Makam Sunan Giri dan masuk melalui gapura depan untuk menuju ke Kompleks Makam Sunan Giri. Pada Iahan parkir terdapat banyak PKL yang berjualan di depan pintu gerbang

2. Peziarah melakukan aktifitas berjalan kaki, melihat makam. Banyak terdapat pengemis

3. Peziarah melakukan ritual ziarah, berdoa di kompleks Makam Sunan Giri

4.Peziarah I'tikaf pada Malam Selawe dan menginap di Kompleks Masjid

5. Peziarah melakukan ritual ziarah pada esok harinya

6. Peziarah membeli oleh-oleh di stand PKL

7. Peziarah menuju gerbang keluar

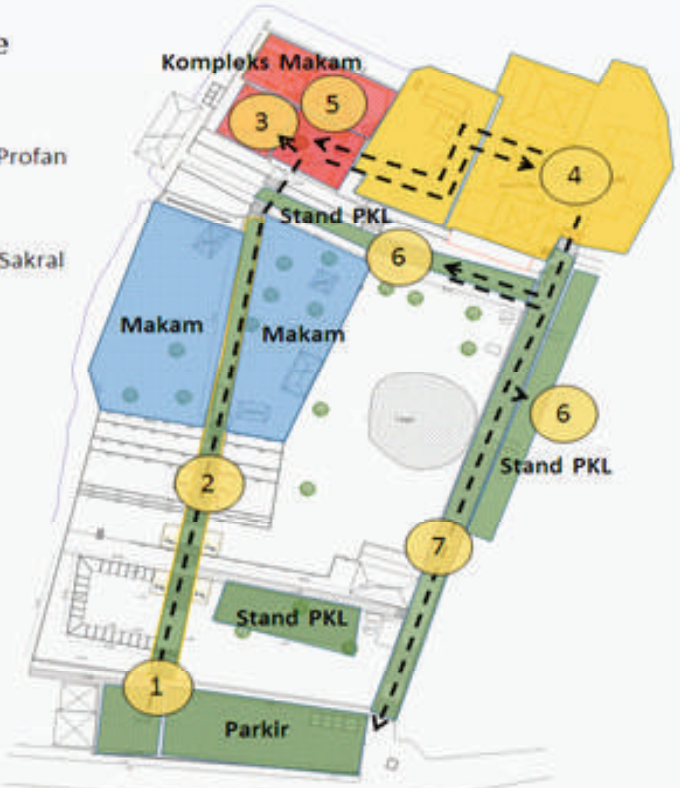

Gambar 4. Penggunaan Ruang saat Malam Selawe 


\section{Identifikasi dan Analisis Penggunaan Ruang Makam Sunan Giri Pada Saat Acara Haul Sunan Giri}

Haul Sunan Giri diadakan setiap Jumat terakhir bulan Robiul Awwal. Haul biasanya berlangsung selama 3 (tiga) hari. Pada saat Haul Sunan Giri, terjadi perubahan aktivitas pengguna. Aktivitas pengguna biasanya selain mengunjungi makam juga mengikuti pengajian dan tahlil akbar yang diselenggarakan di tempat parkiran. Untuk tadarus al Quran yang diikuti khusus jamaah putri kemudian dilanjutkan jamaah putra yang dilakukan di komplek masjid. Aktivitas tinggi pada saat Haul Sunan Giri adalah aktivitas peziarah di makam utama, aktivitas peziarah di stand PKL, aktivitas peziarah di parkiran untuk melakukan kegiatan pengajian akbar.

Tabel 4. Penggunaan Ruang pada Makam Sunan Giri saat Malam Haul Sunan Giri

\begin{tabular}{|l|l|l|l|}
\hline Tempat & Kegiatan & Kondisi Sehari-hari & Saat Haul Sunan Giri \\
\hline Parkir & $\begin{array}{l}\text { Parkir } \\
\text { kendaraan dan } \\
\text { pemberhentian } \\
\text { kendaraan }\end{array}$ & $\begin{array}{l}\text { Tidak dipenuhi oleh } \\
\text { kendaraan }\end{array}$ & $\begin{array}{l}\text { Tempat parkir } \\
\text { digunakan untuk } \\
\text { pengajian dana tahlil } \\
\text { akbar } \\
\text { Terdapat panggung di } \\
\text { parkiran } \\
\text { Parkiran sementara } \\
\text { disediakan masyarakat } \\
\text { secara swadaya }\end{array}$ \\
\hline $\begin{array}{l}\text { Jalur } \\
\text { menuju } \\
\text { Makam }\end{array}$ & $\begin{array}{l}\text { Lalu lintas } \\
\text { pejalan kaki, } \\
\text { ruang publik }\end{array}$ & $\begin{array}{l}\text { Pada hari biasa juga } \\
\text { terdapat pengemis, } \\
\text { namun hanya } \\
\text { beberapa }\end{array}$ & $\begin{array}{l}\text { Pada saat Haul Sunan } \\
\text { Giri, pengemis berada } \\
\text { di jalur menuju makam } \\
\text { dan di dekat tempat } \\
\text { pengajian akbar }\end{array}$ \\
\hline
\end{tabular}

el Harakah Vol.16 No.2 Tahun 2014 


\begin{tabular}{|c|c|c|c|}
\hline Tempat & Kegiatan & Kondisi Sehari-hari & Saat Haul Sunan Giri \\
\hline $\begin{array}{l}\text { Pendopo } \\
\text { dan } \\
\text { Makam } \\
\text { Utama } \\
\text { Sunan } \\
\text { Giri }\end{array}$ & $\begin{array}{l}\text { Wudhu, } \\
\text { berdoa, } \\
\text { membaca } \\
\text { al Quran, } \\
\text { shalawatan }\end{array}$ & $\begin{array}{l}\text { Pada hari biasa, } \\
\text { jumlah pengunjung } \\
\text { antara 50-an orang } \\
\text { per hari }\end{array}$ & $\begin{array}{l}\text { Pada saat Haul Sunan } \\
\text { Giri, dipenuhi oleh } \\
\text { ribuan pengunjung } \\
\text { terutama rombongan } \\
\text { untuk melakukan } \\
\text { pengajian akbar dan } \\
\text { berziarah }\end{array}$ \\
\hline $\begin{array}{l}\text { Stand } \\
\text { PKL }\end{array}$ & $\begin{array}{l}\text { Berjualan dan } \\
\text { membeli }\end{array}$ & $\begin{array}{l}\text { Pada hari biasa, } \\
\text { stand PKL sepi hanya } \\
\text { terdapat beberapa } \\
\text { peziarah yang } \\
\text { membeli }\end{array}$ & $\begin{array}{l}\text { Pada saat Haul Sunan } \\
\text { Giri, stand dipenuhi } \\
\text { oleh penjual dan } \\
\text { peziarah. Para PKL tidak } \\
\text { hanya terdapat pada } \\
\text { tempat yang disediakan } \\
\text { namun juga terdapat di } \\
\text { jalanan menuju Makam } \\
\text { Sunan Giri. }\end{array}$ \\
\hline Masjid & $\begin{array}{l}\text { Sholat, wudhu, } \\
\text { istirahat }\end{array}$ & $\begin{array}{l}\text { Pada hari biasa, hanya } \\
\text { digunakan untuk } \\
\text { sholat }\end{array}$ & $\begin{array}{l}\text { Pada saat Haul Sunan } \\
\text { Giri, masjid digunakan } \\
\text { untuk tadarus al Quran }\end{array}$ \\
\hline
\end{tabular}

Sumber: Dokumentasi Pribadi (2014)

el Harakah Vol.16 No.2 Tahun 2014 


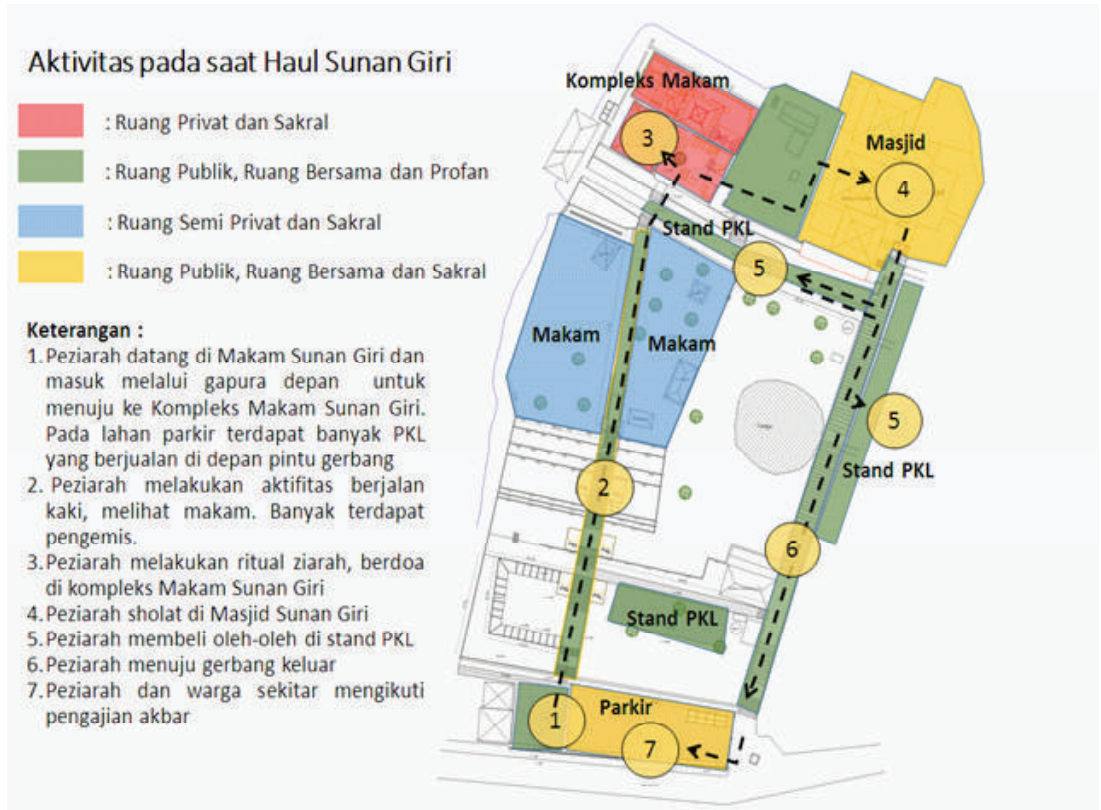

Gambar 5. Penggunaan Ruang saat Malam Haul

\section{Identifikasi dan Analisis Dinamika/Perubahan Ruang Makam Sunan Giri}

Perubahan ruang Makam Sunan Giri dapat ditinjau dari perubahan massa bangunan dan aktivitas pengguna dalam Makam Sunan Giri serta batasan ruang.

a. Perubahan Massa Bangunan

Berdasarkan luasan dari tahun 2010-2013, perubahan ruang berdasarkan luasan dan jumlah ruang di dalam makam Sunan Giri tidak mengalami perubahan yang signifikan. Perubahan ruang hanya terjadi pada pembangunan Kantor Yayasan Makam Sunan Giri seluas 75 m2 dan pembangunan lahan kosong yang dikembangkan menjadi bangunan pendukung makam. Perubahan ruang di Makam Sunan Giri juga terjadi pada Tahun 2013 yaitu pembuatan taman dan pembangunan kios PKL dan lahan paving terbuka. Penambahan jenis dan jumlah ruang itu dipengaruhi oleh estetika dan aktivitas PKL yang mengganggu kenyamanan peziarah. 

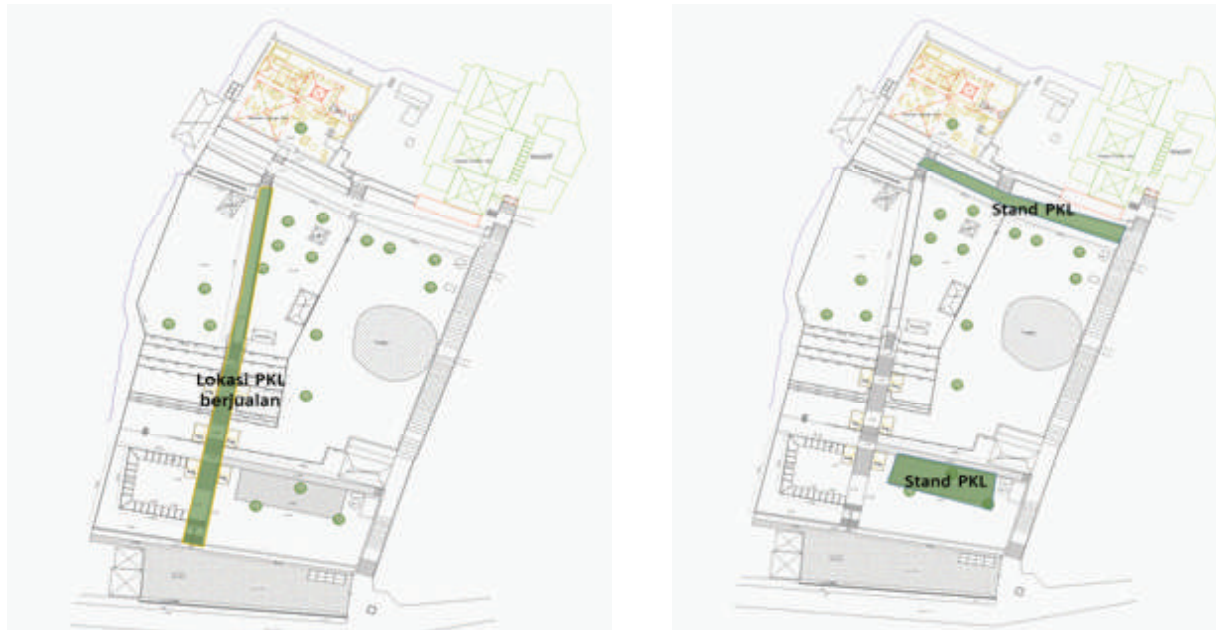

Gambar 6. Perubahan Ruang PKL

b. Perubahan Identitas Bangunan

Terdapat perubahan yang dilakukan oleh Pemerintah Kabupaten Gresik terhadap Makam Sunan Giri yaitu pembangunan dinding penahan pada area halaman gerbang pintu masuk dan pembangunan gapura utama. Meskipun telah mengalami beberapa pemugaran pada gerbang masuk dan fisik bangunan masjid, namun identitas bangunan berlanggam arsitektural tradisional tetap tercermin pada bangunan gerbang dan masjid.
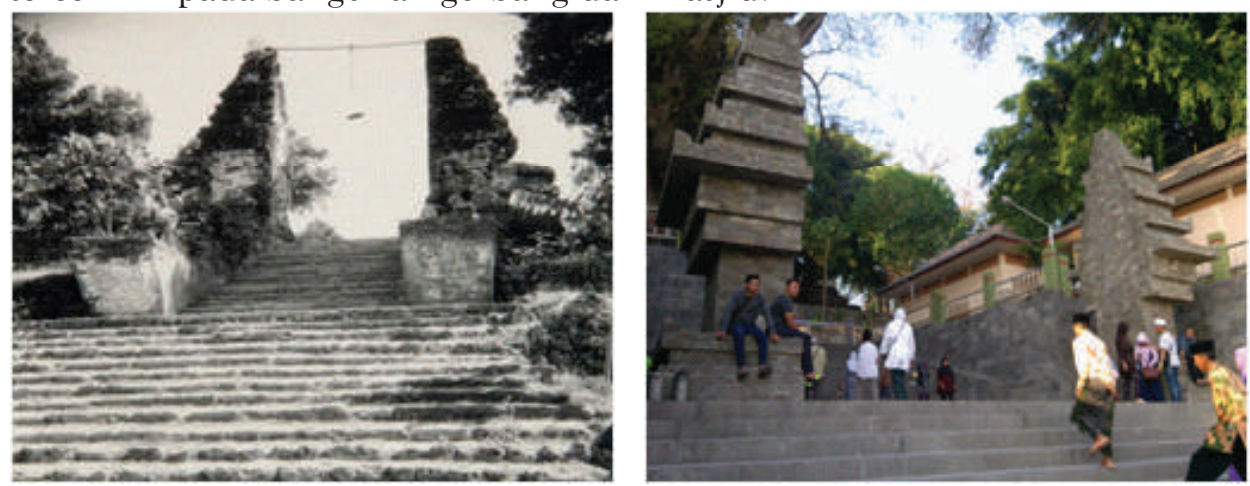

Gambar 7. Identitas Gerbang Masuk Makam Sunan Giri tetap sama dari waktu ke waktu

\section{Identifikasi dan Analisis Perubahan Fungsi Ruang di Makam Sunan Giri}

Perubahan fungsi ruang di Makam Sunan Giri terjadi secara dinamis yang berproses karena perubahan jenis aktivitas.Aktivitas yang bersifat sakral seperti ziarah, sholat menggunakan ruang yang sakral yaitu Kompleks Makam 
dan masjid. Sedangkan untuk aktivitas yang profane seperti kegiatan membeli oleh-oleh dilakukan pada ruang yang bersifat publik. Aktivitas skaral lainnya namun menggunakan ruang publik adalah aktivitas pengajian akbar yang menggunakan ruang parkir dan halaman depan gerbang masuk, Suatu ruang sebagai wadah karena suatu aktivitas yang ada di dalamnya dapat berubah lebih sakral dengan didukung adanya atribut ruang dan aktivitas itu sendiri. Teritori ruang mempunyai dinamika ketika aktivitas yang dilakukan berbeda.

\section{Ruang Parkir dan Ruang Depan Gerbang}

Aktivitas di ruang parkir dan ruang derpan gerbang masuk pada saat hari biasa, hari libur dan saat acara tertentu mengalami perubahan yang dikarenakan jenis aktivitas. Tipologi ruang saat hari biasa, hari libur dan Malam Selawe yaitu ruang publik dan sifatnya profan. Namun pada saat haul bersifat sakral.

Tabel 5. Analisis perubahan fungsi ruang di area parkir dan depan gerbang

\begin{tabular}{|c|c|c|c|c|}
\hline Aspek & $\begin{array}{l}\text { Hari Biasa dan } \\
\text { Hari Libur }\end{array}$ & Malam Selawe & $\begin{array}{l}\text { Haul Sunan } \\
\text { Giri }\end{array}$ & Ket. \\
\hline Aktivitas & $\begin{array}{l}\text { Peziarah datang, } \\
\text { memarkir } \\
\text { kendaraan dan } \\
\text { menuju gerbang } \\
\text { masuk } \\
\text { Tidak terdapat } \\
\text { PKL }\end{array}$ & $\begin{array}{l}\text { Digunakan } \\
\text { PKL untuk } \\
\text { berjualan } \\
\text { Parkir peziarah } \\
\text { di rumah warga } \\
\text { Banyak } \\
\text { terdapat } \\
\text { pengemis di } \\
\text { depan pintu } \\
\text { gerbang }\end{array}$ & $\begin{array}{l}\text { Digunakan } \\
\text { untuk } \\
\text { pengajian } \\
\text { akbar } \\
\text { parkir } \\
\text { peziarah di } \\
\text { rumah warga }\end{array}$ & $\begin{array}{l}\text { Terjadi } \\
\text { perubahan } \\
\text { fungsi } \\
\text { ruang yang } \\
\text { dikarenakan } \\
\text { jenis aktivitas } \\
\text { Perubahan } \\
\text { bersifat } \\
\text { dinamis } \\
\text { terjadi pada } \\
\text { saat acara } \\
\text { tertentu }\end{array}$ \\
\hline $\begin{array}{l}\text { Pelaku } \\
\text { Kegiatan }\end{array}$ & $\begin{array}{l}\text { Peziarah, } \\
\text { Tukang Ojeg, } \\
\text { Tukang Parkir }\end{array}$ & $\begin{array}{l}\text { Peziarah, } \\
\text { pedagang, } \\
\text { warga sekitar, } \\
\text { pengemis }\end{array}$ & $\begin{array}{l}\text { Warga } \\
\text { sekitar, } \\
\text { peziarah }\end{array}$ & \\
\hline
\end{tabular}




\begin{tabular}{|c|c|c|c|c|}
\hline Aspek & $\begin{array}{l}\text { Hari Biasa dan } \\
\text { Hari Libur }\end{array}$ & Malam Selawe & $\begin{array}{l}\text { Haul Sunan } \\
\text { Giri }\end{array}$ & Ket. \\
\hline $\begin{array}{l}\text { Tipologi } \\
\text { Ruang }\end{array}$ & $\begin{array}{l}\text { Ruang Publik, } \\
\text { ruang bersama }\end{array}$ & $\begin{array}{l}\text { Ruang Publik, } \\
\text { ruang bersama }\end{array}$ & $\begin{array}{l}\text { Ruang } \\
\text { Publik, } \\
\text { ruang } \\
\text { bersama }\end{array}$ & \\
\hline $\begin{array}{l}\text { Fisik } \\
\text { Ruang }\end{array}$ & $\begin{array}{l}\text { Elemen fix: } \\
\text { lahan parkir } \\
\text { mobil dan } \\
\text { motor } \\
\text { Elemen semi fix: } \\
\text { Atap penutup } \\
\text { parkir } \\
\text { Elemen non fix: } \\
\text { peziarah yang } \\
\text { memarkirkan } \\
\text { kendaraannya }\end{array}$ & $\begin{array}{l}\text { Elemen fix: } \\
\text { lahan parkir } \\
\text { mobil dan } \\
\text { motor } \\
\text { Elemen } \\
\text { semi fix: } \\
\text { lahan untuk } \\
\text { berjualan para } \\
\text { pedagang } \\
\text { Elemen non } \\
\text { fix: peziarah } \\
\text { dan warga } \\
\text { sekitar } \\
\text { melakukan } \\
\text { aktivitas jual } \\
\text { beli }\end{array}$ & $\begin{array}{l}\text { Elemen fix: } \\
\text { lahan parkir } \\
\text { mobil dan } \\
\text { motor } \\
\text { Elemen semi } \\
\text { fix : Atap } \\
\text { penutup } \\
\text { parkir } \\
\text { Elemen } \\
\text { non fix : } \\
\text { peziarah yang } \\
\text { memarkirkan } \\
\text { kendaraannya }\end{array}$ & \\
\hline $\begin{array}{l}\text { Setting } \\
\text { Ruang }\end{array}$ & $\begin{array}{l}\text { Kenyamanan: } \\
\text { kelapangan, } \\
\text { keleluasaan } \\
\text { Aksesibilitas: } \\
\text { mudah diakses } \\
\text { Ruang } \\
\text { personal/sosial: } \\
\text { ruang sosial }\end{array}$ & $\begin{array}{l}\text { Kenyamanan: } \\
\text { kelapangan, } \\
\text { keleluasaan } \\
\text { Aksesibilitas: } \\
\text { mudah diakses } \\
\text { Ruang } \\
\text { personal/ } \\
\text { sosial: ruang } \\
\text { sosial }\end{array}$ & $\begin{array}{l}\text { Kenyamanan: } \\
\text { sakral } \\
\text { Aksesibilitas: } \\
\text { mudah } \\
\text { diakses } \\
\text { Ruang } \\
\text { personal/ } \\
\text { sosial: ruang } \\
\text { sosial }\end{array}$ & \\
\hline
\end{tabular}

Sumber: Dokumentasi Pribadi (2014)

\section{Ruang Pejalan Kaki Menuju Makam}

Aktivitas di pejalan kaki menuju makam pada saat hari biasa, hari libur dan saat acara tertentu tidak mengalami perubahan yang signifikan, hanya terjadi peningkatan aktivitas yaitu aktivitas pengemis. 
Tabel 6. Analisis perubahan fungsi ruang di area pejalan kaki menuju makam

\begin{tabular}{|c|c|c|c|c|}
\hline Aspek & $\begin{array}{l}\text { Hari Biasa dan } \\
\text { Hari Libur }\end{array}$ & Malam Selawe & $\begin{array}{l}\text { Haul Sunan } \\
\text { Giri }\end{array}$ & Ket. \\
\hline Aktivitas & $\begin{array}{l}\text { Peziarah } \\
\text { melakukan } \\
\text { aktivitas berjalan } \\
\text { kaki menuju } \\
\text { Kompleks } \\
\text { Makam dan } \\
\text { melihat makam } \\
\text { di sisi kanan kiri } \\
\text { Terdapat } \\
\text { pengemis } \\
\text { namun tidak } \\
\text { banyak }\end{array}$ & $\begin{array}{l}\text { Peziarah } \\
\text { melakukan } \\
\text { aktivitas } \\
\text { berjalan } \\
\text { kaki menuju } \\
\text { Kompleks } \\
\text { Makam dan } \\
\text { melihat makam } \\
\text { di sisi kanan } \\
\text { kiri } \\
\text { Banyak terdapat } \\
\text { pengemis dan } \\
\text { mengganggu } \\
\text { kenyamanan } \\
\text { pejalan kaki }\end{array}$ & $\begin{array}{l}\text { Peziarah } \\
\text { melakukan } \\
\text { aktivitas } \\
\text { berjalan } \\
\text { kaki menuju } \\
\text { Kompleks } \\
\text { Makam dan } \\
\text { melihat } \\
\text { makam di sisi } \\
\text { kanan kiri } \\
\text { Banyak } \\
\text { terdapat } \\
\text { pengemis } \\
\text { dan } \\
\text { mengganggu } \\
\text { kenyamanan } \\
\text { pejalan kaki }\end{array}$ & $\begin{array}{l}\text { Tidak } \\
\text { terjadi } \\
\text { perubahan } \\
\text { fungsi hanya } \\
\text { terjadi } \\
\text { peningkatan } \\
\text { aktivitas } \\
\text { pengemis }\end{array}$ \\
\hline $\begin{array}{l}\text { Pelaku } \\
\text { Kegiatan }\end{array}$ & $\begin{array}{l}\text { Peziarah, } \\
\text { pengemis }\end{array}$ & $\begin{array}{l}\text { Peziarah, } \\
\text { pengemis }\end{array}$ & $\begin{array}{l}\text { Peziarah, } \\
\text { pengemis }\end{array}$ & \\
\hline $\begin{array}{l}\text { Tipologi } \\
\text { Ruang }\end{array}$ & $\begin{array}{l}\text { Ruang Publik, } \\
\text { ruang peralihan }\end{array}$ & $\begin{array}{l}\text { Ruang Publik, } \\
\text { ruang peralihan }\end{array}$ & $\begin{array}{l}\text { Ruang } \\
\text { Publik, ruang } \\
\text { peralihan }\end{array}$ & \\
\hline
\end{tabular}




\begin{tabular}{|c|c|c|c|c|}
\hline Aspek & $\begin{array}{l}\text { Hari Biasa dan } \\
\text { Hari Libur }\end{array}$ & Malam Selawe & $\begin{array}{l}\text { Haul Sunan } \\
\text { Giri }\end{array}$ & Ket. \\
\hline Fisik Ruang & $\begin{array}{l}\text { Elemen fix: } \\
\text { bangunan } \\
\text { makam di } \\
\text { kanan kiri ruang } \\
\text { pejalan kaki } \\
\text { Elemen semi fix: } \\
\text { ruang pejalan } \\
\text { kaki } \\
\text { Elemen non } \\
\text { fix: peziarah } \\
\text { berjalan kaki }\end{array}$ & $\begin{array}{l}\text { Elemen fix: } \\
\text { bangunan } \\
\text { makam di } \\
\text { kanan kiri } \\
\text { ruang pejalan } \\
\text { kaki } \\
\text { Elemen semi } \\
\text { fix: ruang } \\
\text { pejalan kaki } \\
\text { Elemen non } \\
\text { fix: peziarah } \\
\text { berjalan kaki }\end{array}$ & $\begin{array}{l}\text { Elemen fix: } \\
\text { bangunan } \\
\text { makam di } \\
\text { kanan kiri } \\
\text { ruang pejalan } \\
\text { kaki } \\
\text { Elemen semi } \\
\text { fix: ruang } \\
\text { pejalan kaki } \\
\text { Elemen non } \\
\text { fix: peziarah } \\
\text { berjalan kaki }\end{array}$ & $\begin{array}{l}\text { Tidak } \\
\text { terjadi } \\
\text { perubahan } \\
\text { fungsi hanya } \\
\text { terjadi } \\
\text { peningkatan } \\
\text { aktivitas } \\
\text { pengemis }\end{array}$ \\
\hline $\begin{array}{l}\text { Setting } \\
\text { Ruang }\end{array}$ & $\begin{array}{l}\text { Kenyamanan: } \\
\text { kelapangan, } \\
\text { keleluasaan } \\
\text { Aksesibilitas: } \\
\text { mudah diakses } \\
\text { Ruang personal/ } \\
\text { sosial: ruang } \\
\text { sosial }\end{array}$ & $\begin{array}{l}\text { Kenyamanan: } \\
\text { kenyamanan } \\
\text { terganggu } \\
\text { Aksesibilitas: } \\
\text { mudah diakses } \\
\text { Ruang } \\
\text { personal/sosial: } \\
\text { ruang sosial }\end{array}$ & $\begin{array}{l}\text { Kenyamanan: } \\
\text { kenyamanan } \\
\text { terganggu } \\
\text { Aksesibilitas: } \\
\text { mudah } \\
\text { diakses } \\
\text { Ruang } \\
\text { personal/ } \\
\text { sosial: ruang } \\
\text { sosial }\end{array}$ & $\begin{array}{l}\text { Tidak } \\
\text { terjadi } \\
\text { perubahan } \\
\text { fungsi hanya } \\
\text { terjadi } \\
\text { peningkatan } \\
\text { aktivitas } \\
\text { pengemis }\end{array}$ \\
\hline
\end{tabular}

Sumber: Dokumentasi Pribadi (2014)

\section{Ruang Kompleks Makam}

Aktivitas di Kompleks Makam Sunan Giri pada saat hari biasa, hari libur dan saat acara tertentu tidak mengalami perubahan yang signifikan, namun hanya terjadi peningkatan jumlah peziarah sehingga harus membutuhkan alternatif ruang untuk menampung para peziarah pada saat Malam Selawe dan Haul. Tipologi ruang di area kompleks makam adalah bersifat sakral. 
Tabel 7. Analisis perubahan fungsi ruang di Kompleks Makam

\begin{tabular}{|c|c|c|c|c|}
\hline Aspek & $\begin{array}{l}\text { Hari Biasa dan } \\
\text { Hari Libur }\end{array}$ & Malam Selawe & $\begin{array}{l}\text { Haul Sunan } \\
\text { Giri }\end{array}$ & Ket. \\
\hline Aktivitas & $\begin{array}{l}\text { Peziarah } \\
\text { melakukan ritual } \\
\text { religi (berdoa, } \\
\text { berziarah) } \\
\text { Peziarah } \\
\text { beristirahat di } \\
\text { pendopo }\end{array}$ & $\begin{array}{l}\text { Peziarah } \\
\text { melakukan } \\
\text { ritual religi } \\
\text { (berdoa, } \\
\text { berziarah) } \\
\text { Peziarah } \\
\text { beristirahat dan } \\
\text { menunggu di } \\
\text { pendopo }\end{array}$ & $\begin{array}{l}\text { Peziarah } \\
\text { melakukan } \\
\text { ritual religi } \\
\text { (berdoa, } \\
\text { berziarah) } \\
\text { Peziarah } \\
\text { beristirahat } \\
\text { dan menunggu } \\
\text { di pendopo } \\
\end{array}$ & \multirow{5}{*}{$\begin{array}{l}\text { Tidak } \\
\text { terjadi } \\
\text { peruba- } \\
\text { han fungsi } \\
\text { ruang } \\
\text { namun } \\
\text { hanya ter- } \\
\text { jadi pen- } \\
\text { ingkatan } \\
\text { jumlah } \\
\text { peziarah } \\
\text { sehingga } \\
\text { harus } \\
\text { membu- } \\
\text { tuhkan } \\
\text { alternatif } \\
\text { ruang } \\
\text { untuk } \\
\text { menam- } \\
\text { pung para } \\
\text { peziarah } \\
\text { pada saat } \\
\text { Malam Se- } \\
\text { lawe dan } \\
\text { Haul. }\end{array}$} \\
\hline $\begin{array}{l}\text { Pelaku } \\
\text { Kegiatan }\end{array}$ & $\begin{array}{l}\text { Peziarah, penjaga } \\
\text { makam }\end{array}$ & $\begin{array}{l}\text { Peziarah, warga } \\
\text { sekitar, penjaga } \\
\text { makam }\end{array}$ & $\begin{array}{l}\text { Peziarah, warga } \\
\text { sekitar penjaga } \\
\text { makam, }\end{array}$ & \\
\hline $\begin{array}{l}\text { Tipologi } \\
\text { Ruang }\end{array}$ & Ruang privat & Ruang privat & Ruang privat & \\
\hline Fisik Ruang & $\begin{array}{l}\text { Elemen fix: } \\
\text { bangunan } \\
\text { makam dan } \\
\text { pendopo } \\
\text { Elemen semi fix: } \\
\text { tiang, atap } \\
\text { Elemen non } \\
\text { fix: peziarah } \\
\text { melakukan ritual } \\
\text { ziarah }\end{array}$ & $\begin{array}{l}\text { Elemen fix: } \\
\text { bangunan } \\
\text { makam dan } \\
\text { pendopo } \\
\text { Elemen semi } \\
\text { fix: tiang, atap } \\
\text { Elemen non } \\
\text { fix: peziarah } \\
\text { melakukan } \\
\text { ritual ziarah } \\
\end{array}$ & $\begin{array}{l}\text { Elemen fix: } \\
\text { bangunan } \\
\text { makam dan } \\
\text { pendopo } \\
\text { Elemen semi } \\
\text { fix : tiang, atap } \\
\text { Elemen non } \\
\text { fix: peziarah } \\
\text { melakukan } \\
\text { ritual ziarah } \\
\end{array}$ & \\
\hline $\begin{array}{l}\text { Setting } \\
\text { Ruang }\end{array}$ & $\begin{array}{l}\text { Kenyamanan: } \\
\text { sakral } \\
\text { Aksesibilitas: } \\
\text { mudah diakses } \\
\text { Ruang personal/ } \\
\text { sosial: ruang } \\
\text { personal }\end{array}$ & $\begin{array}{l}\text { Kenyamanan: } \\
\text { sakral } \\
\text { Aksesibilitas: } \\
\text { mudah diakses } \\
\text { Ruang } \\
\text { personal/sosial: } \\
\text { ruang personal }\end{array}$ & $\begin{array}{l}\text { Kenyamanan: } \\
\text { sakral } \\
\text { Aksesibilitas: } \\
\text { mudah diakses } \\
\text { Ruang } \\
\text { personal/ } \\
\text { sosial: ruang } \\
\text { personal }\end{array}$ & \\
\hline
\end{tabular}

Sumber: Dokumentasi Pribadi (2014) 
Tabel 8. Analisis perubahan fungsi ruang di Kompleks Masjid Sunan Giri

\begin{tabular}{|c|c|c|c|c|}
\hline Aspek & $\begin{array}{l}\text { Hari Biasa dan } \\
\text { Hari Libur }\end{array}$ & $\begin{array}{l}\text { Malam } \\
\text { Selawe }\end{array}$ & $\begin{array}{l}\text { Haul Sunan } \\
\text { Giri }\end{array}$ & Ket. \\
\hline Aktivitas & $\begin{array}{l}\text { Peziarah } \\
\text { melakukan } \\
\text { sholat } \\
\text { Peziarah beristi- } \\
\text { rahat di masjid }\end{array}$ & $\begin{array}{l}\text { Peziarah } \\
\text { melakukan } \\
\text { sholat } \\
\text { Peziarah } \\
\text { melakukan } \\
\text { I'tikaf }\end{array}$ & $\begin{array}{l}\text { Peziarah } \\
\text { melakukan } \\
\text { sholat } \\
\text { Digunakan } \\
\text { untuk kegia- } \\
\text { tan MTQ dan } \\
\text { Khataman } \\
\text { Qur'an }\end{array}$ & $\begin{array}{l}\text { Terjadi } \\
\text { perubahan } \\
\text { fungsi ruang } \\
\text { yang dikar- } \\
\text { enakan jenis } \\
\text { aktivitas } \\
\text { Perubahan } \\
\text { bersifat dina- } \\
\text { mis terjadi } \\
\text { pada saat ac- } \\
\text { ara tertentu }\end{array}$ \\
\hline $\begin{array}{l}\text { Pelaku Kegia- } \\
\text { tan }\end{array}$ & Peziarah & $\begin{array}{l}\text { Peziarah, } \\
\text { warga seki- } \\
\text { tar }\end{array}$ & $\begin{array}{l}\text { Peziarah, } \\
\text { warga sekitar }\end{array}$ & \\
\hline $\begin{array}{l}\text { Tipologi } \\
\text { Ruang }\end{array}$ & Ruang privat & $\begin{array}{l}\text { Ruang } \\
\text { privat }\end{array}$ & $\begin{array}{l}\text { Ruang ber- } \\
\text { sama }\end{array}$ & \\
\hline Fisik Ruang & $\begin{array}{l}\text { Elemen fix: ban- } \\
\text { gunan masjid } \\
\text { Elemen semi fix } \\
\text { : atap, mimbar, } \\
\text { serambi, teras } \\
\text { Elemen non } \\
\text { fix: peziarah } \\
\text { melakukan } \\
\text { sholat }\end{array}$ & $\begin{array}{l}\text { Elemen fix: } \\
\text { bangunan } \\
\text { masjid } \\
\text { Elemen } \\
\text { semi fix: } \\
\text { atap, mim- } \\
\text { bar, seram- } \\
\text { bi, teras } \\
\text { Elemen non } \\
\text { fix: peziarah } \\
\text { melakukan } \\
\text { sholat dan } \\
\text { I'tikaf }\end{array}$ & $\begin{array}{l}\text { Elemen fix: } \\
\text { bangunan } \\
\text { masjid } \\
\text { Elemen semi } \\
\text { fix: atap, } \\
\text { mimbar, se- } \\
\text { rambi, teras } \\
\text { Elemen non } \\
\text { fix: peziarah } \\
\text { melakukan } \\
\text { sholat dan } \\
\text { terdapat keg- } \\
\text { iatan MTQ } \\
\text { dan khata- } \\
\text { man Qur'an }\end{array}$ & \\
\hline
\end{tabular}




\begin{tabular}{|l|l|l|l|l|}
\hline Aspek & $\begin{array}{l}\text { Hari Biasa dan } \\
\text { Hari Libur }\end{array}$ & $\begin{array}{l}\text { Malam } \\
\text { Selawe }\end{array}$ & $\begin{array}{l}\text { Haul Sunan } \\
\text { Giri }\end{array}$ & Ket. \\
\hline Setting Ruang & $\begin{array}{l}\text { Kenyamanan: } \\
\text { sakral }\end{array}$ & $\begin{array}{l}\text { Kenyaman- } \\
\text { an: sakral }\end{array}$ & $\begin{array}{l}\text { Kenyamanan: } \\
\text { sakral }\end{array}$ & \\
& Aksesibilitas: & Aksesibili- & Aksesibili- \\
& mudah diakses & tas: mudah & tas: mudah & \\
& Ruang person- & diakses & diakses \\
& al/sosial: ruang & Ruang & Ruang per- \\
personal/ & sonal/sosial: & \\
& personal & ruang sosial & \\
& & personal & & \\
& & & \\
& &
\end{tabular}

Sumber: Dokumentasi Pribadi (2014)

\section{Ruang Kompleks Masjid}

Aktivitas di Kompleks Masjid Sunan Giri pada saat hari biasa, hari libur dan saat acara tertentu mengalami perubahan yang dikarenakan jenis aktivitas.Tipologi ruang saat hari biasa, hari libur dan Malam Selawe yaitu ruang privat dan sifatnya sakral. Namun pada saat haul, tipologi ruangnya adalah ruang bersama dan ruang publik.

\section{Ruang Pejalan kaki menuju gerbang keluar}

Aktivitas di Kompleks Masjid Sunan Giri pada saat hari biasa, hari libur dan saat acara tertentu mengalami perubahan yang dikarenakan jenis aktivitas. Pada saat acara agama, kenyaman pejalan kaki melakukan aktivitas membeli terganggu oleh keberadaan pengemis untuk itu perlu ada regulasi dan pengaturan pada pengemis di ruang pejalan kaki. 
Tabel 9. Analisis perubahan fungsi ruang di area pejalan kaki menuju gerbang keluar

\begin{tabular}{|c|c|c|c|c|}
\hline Aspek & $\begin{array}{l}\text { Hari Biasa } \\
\text { dan Hari } \\
\text { Libur }\end{array}$ & Malam Selawe & $\begin{array}{l}\text { Haul Sunan } \\
\text { Giri }\end{array}$ & Ket. \\
\hline Aktivitas & $\begin{array}{l}\text { Peziarah mem- } \\
\text { beli oleh-oleh di } \\
\text { stand PKL }\end{array}$ & $\begin{array}{l}\text { Peziarah membeli } \\
\text { oleh-oleh di stand } \\
\text { PKL } \\
\text { Terdapat ban- } \\
\text { yak pengemis di } \\
\text { ruang pejalan kaki } \\
\text { menuju gerbang }\end{array}$ & $\begin{array}{l}\text { Peziarah membeli } \\
\text { oleh-oleh di stand } \\
\text { PKL } \\
\text { Terdapat banyak } \\
\text { pengemis di ru- } \\
\text { ang pejalan kaki } \\
\text { menuju gerbang }\end{array}$ & \multirow{5}{*}{$\begin{array}{l}\text { Terjadi peruba- } \\
\text { han fungsi } \\
\text { ruang yang } \\
\text { dikarenakan } \\
\text { jenis aktivitas } \\
\text { Perubahan ber- } \\
\text { sifat dinamis } \\
\text { terjadi pada } \\
\text { saat acara } \\
\text { tertentu } \\
\text { Perlu ada } \\
\text { regulasi dan } \\
\text { pengaturan } \\
\text { pada pengemis } \\
\text { di ruang pe- } \\
\text { jalan kaki }\end{array}$} \\
\hline $\begin{array}{l}\text { Pelaku } \\
\text { Kegiatan }\end{array}$ & $\begin{array}{l}\text { Peziarah, peda- } \\
\text { gang }\end{array}$ & $\begin{array}{l}\text { Peziarah, pedagang, } \\
\text { pengemis }\end{array}$ & $\begin{array}{l}\text { Peziarah, peda- } \\
\text { gang, pengemis }\end{array}$ & \\
\hline $\begin{array}{l}\text { Tipologi } \\
\text { Ruang }\end{array}$ & $\begin{array}{l}\text { Ruang publik } \\
\text { dan ruang } \\
\text { bersama }\end{array}$ & $\begin{array}{l}\text { Ruang publik dan } \\
\text { ruang bersama }\end{array}$ & $\begin{array}{l}\text { Ruang publik } \\
\text { dan ruang ber- } \\
\text { sama }\end{array}$ & \\
\hline $\begin{array}{l}\text { Fisik } \\
\text { Ruang }\end{array}$ & $\begin{array}{l}\text { Elemen fix: } \\
\text { bangunan stand } \\
\text { PKL } \\
\text { Elemen semi fix } \\
\text { : ruang pejalan } \\
\text { kaki } \\
\text { Elemen non fix: } \\
\text { peziarah mem- } \\
\text { beli oleh-oleh }\end{array}$ & $\begin{array}{l}\text { Elemen fix: bangu- } \\
\text { nan stand PKL } \\
\text { Elemen semi fix: } \\
\text { ruang pejalan kaki } \\
\text { Elemen non fix : } \\
\text { peziarah membeli } \\
\text { oleh-oleh dan } \\
\text { memberi sedekah } \\
\text { pada pengemis }\end{array}$ & $\begin{array}{l}\text { Elemen fix: ban- } \\
\text { gunan stand PKL } \\
\text { Elemen semi fix: } \\
\text { ruang pejalan } \\
\text { kaki } \\
\text { Elemen non fix: } \\
\text { peziarah membeli } \\
\text { oleh-oleh dan } \\
\text { memberi sedekah } \\
\text { pada pengemis }\end{array}$ & \\
\hline $\begin{array}{l}\text { Setting } \\
\text { Ruang }\end{array}$ & $\begin{array}{l}\text { Kenyamanan: } \\
\text { keleluasan, } \\
\text { kelapangan } \\
\text { Aksesibilitas: } \\
\text { mudah diakses } \\
\text { Ruang person- } \\
\text { al/sosial: ruang } \\
\text { sosial }\end{array}$ & $\begin{array}{l}\text { Kenyamanan: kele- } \\
\text { luasan, kelapangan } \\
\text { namun terganggu } \\
\text { oleh keberadaan } \\
\text { pengemis } \\
\text { Aksesibilitas: mu- } \\
\text { dah diakses } \\
\text { Ruang personal/ } \\
\text { sosial: ruang sosial }\end{array}$ & $\begin{array}{l}\text { Kenyamanan: } \\
\text { keleluasan, kela- } \\
\text { pangan namun } \\
\text { terganggu oleh } \\
\text { keberadaan } \\
\text { pengemis } \\
\text { Aksesibilitas: } \\
\text { mudah diakses } \\
\text { Ruang personal/ } \\
\text { sosial: ruang } \\
\text { sosial }\end{array}$ & \\
\hline
\end{tabular}

Sumber: Dokumentasi Pribadi (2014) 


\section{Simpulan}

Dari hasil dan pembahasan terkait dengan dinamika ruang di Makam Sunan Giri, maka dapat disimpulkan hal-hal sebagai berikut:

a. Pola Aktivitas Publik di makam Sunan Giri

Pola aktivitas publik di makam Sunan Giri tidak terbatas dan bersifat heterogen. Karakteristik pola aktivitas publik di makam Sunan Giri dapat dilihat dari waktu penggunaan, aktivitas yang berlangsung, pengguna dan aspek kualitas ruang. Pola aktivitas di makam Sunan Giri dipengaruhi oleh:

1. Aksesibilitas yaitu ruang pejalan kaki, pendopo dan makam utama Sunan Giri

2. Pendukung aktivitas yaitu ketersediaan PKL, ketersediaan parkir dan peneduhan

3. Even-acara temporer yaitu hari Sabtu-Minggu dan acara haul Sunan Giri dan Malam Selawe.

b. Dinamika Ruang di Makam Sunan Giri

Dari hasil penelahaan, dapat disimpulkan bahwa dinamika ruang di Makam Sunan Giri terjadi dikarenakan adanya konteks waktu dan aktivitas. Disamping itu faktor perilaku keruangan, kepadatan ruang dan intensitas kegiatan dalam ruang turut mempengaruhi kedinamikaan ruang Makam Sunan Giri. Hasil akhir dari penelitian dinamika ruang adalah menunjukkan pola aktivitas yang sangat berbeda pada konteks waktu tertentu. Aktivitas ritual keagamaan di Makam Sunan Giri bersifat temporer atau fleksibal. Ruang yang mengalami perubahan adalah area parkir, kompleks masjid dan ruang pejalan kaki menuju pintu keluar.

\section{Daftar Pustaka}

Al Murtadho, Sayid Husein, dan Abdullah Zaky Al Kaaf, Maman Abd. Djaliel, 1999. Keteladanan dan Perjuangan Wali Songo Dalam Menyiarkan Islam Di Tanah Jawa. CV Pustaka Setia: Bandung.

Ari Wibowo. 2014. Arsitektur e-Journal Penataan Wisata Religi Kompleks Makam Sunan Giri Di Gresik.

Drewes, G. W. J. 1968. New Light on the Coming of Islam to Indonesia. Bijdragen tot de Taal: Land en Volkenkunde.

Dyah, Ivana Sari. 2010. Arsitektur e-Journal Objek Wisata Religi Makam Sunan muria. 
Groeneveldt, W.P. 1960. Historical Notes on Indonesia and Malaya Compiled from Chinese Sources. Jakarta: Bhratara,

Hasyim, Umar. 1981. Riwayat Maulana Malik Ibrahim. Kudus: Menara Kudus.

Hasyim, Umar. 2006. Jejak Para Wali dan Ziarah Spiritual, Penerbit Buku Kompas

Meinsma, J.J., 1903. Serat Babad Tanah Jawi, Wiwit Saking Nabi Adam Dumugi ing Tahun 1647. S'Gravenhage.

Moquette, J.P., 1912. "De oudste Mohammedaansche inscriptie op Java end Madura de graafsteen te Leran”.

Muliadi. 2004. Arsitektur e-Journal Pola Spasial Objek Wisata Ziarah Wali Masjid Menara dan Makam Sunan Kudus Dikaitkan dengan Persepsi Peziarah.

Munif, Drs. Moh.Hasyim. 1995. Pioner EO Pendekar Syiar Islam Tanah Jawa. Gresik: Yayasan Abdi Putra Al Munthasimi.

Raffles, Sir Thomas Stamford, F.R.S. 1830. The History of Java, from the earliest Traditions till the establisment of Mahomedanism. Albemarle-Street: John Murray Vol II, 2nd Ed.

Salam, Solichin, 1960. Sekitar Walisanga. Kudus: Menara Kudus.

Tjandrasasmita, Uka (Ed.). 1984. Sejarah Nasional Indonesia III. Jakarta: PN Balai Pustaka,

Van Bruinessen, Martin, 1994. Najmuddin al Kubra, Jumadil Kubra and Jamaluddin al-Akbar: Traces of Kubrawiyya influence in early Indonesian Islam, Bijdragen tot de Taal-, Land- en Volkenkunde. 